\title{
SEMANTIC ANALYSIS OF FIGURATIVE LANGUAGE EXPRESSIONS IN "FEATURE" OF THE JAKARTA POST
}

\author{
Tri Rohani ${ }^{1}$, Safnil Arsyad ${ }^{2}$, Irma Diani ${ }^{3}$ \\ English Education Postgraduate Program \\ Bengkulu University, Indonesia \\ E-mails: kiehan33@yahoo.com, \\ safnilarsyad@gmail.com, irmabengkulu@yahoo.com
}

\begin{abstract}
This study aims at investigating the types of figurative lexicons and the types of meaning of figurative lexicons found in "feature" of The Jakarta Post's December editions. The methodology of the research used descriptive qualitative content analysis. The findings related to research questions showed that there were thirteen types of figurative lexicons found in "feature" of The Jakarta Post and the most dominant type of figurative lexicon found was simile while for the types of meanings of figurative lexicons found in "feature" of The Jakarta Post, it was found that there were seven types of meanings found in "feature" of the Jakarta Post and the most type of meaning of figurative lexicons found was conceptual meaning. This means that using simile and conceptual meaning in the news presentation of "feature" in The Jakarta Post were effective in order to help the readers easier in understanding the news presented in The Jakarta Post. Therefore, it is then recommended that teachers can bring this type of authentic material to school so the students are motivated and encourged to learn more things in English especially about figurative language and types of meanings.
\end{abstract}

Key Words: figurative lexicon, figurative language, meaning, the jakarta post, "feature"

\begin{abstract}
ABSTRAK
Penelitian ini bertujuan untuk meneliti tipe-tipe kalimat perumpamaan dan tipe-tipe makna dari kalimat perumpamaan yang digunakan di "feature" pada The Jakarta Post edisi Desember. Metode penelitian ini menggunakan deskriptif qualitatif analisa kontent. Hasil yang ditemukan berdasarkan pertanyaan yang ada menunjukkan bahwa ada tiga belas tipe kalimat perumpamaan yang ditemukan di rubrik "feature" pada The Jakarta Post dan tipe yang paling dominan dipakai adalah simile sedangkan untuk tipe-tipe makna dari kalimat perumpamaan yang terdapat di rubrik "feature" pada The Jakarta Post, ditemukan bahwa ada tujuh tipe makna yang dipakai di "feature" pada The Jakarta Post dan yang paling dominan digunakan adalah makna konseptual. Hal ini berarti bahwa penggunaan simile dan makna konseptual dalam penyajian berita di "feature" pada The Jakarta Post sangat efektif dalam membantu para pembaca untuk lebih mudah memahami informasi yang disampaikan. Oleh karena itu, disarankan kepada guru untuk mengajarkan materi ini di sekolah-sekolah agar mahasiswa termotivasi dan terdorong untuk belajar banyak hal dalam bahasa Inggris terutama bahasa perumpamaan dan tipe-tipe makna.
\end{abstract}

Kata Kunci: kalimat perumpamaan, bahasa perumpamaan, makna, Jakarta post, rubrik "feature" 


\section{INTRODUCTION}

Figurative language is a language aspect in which an expression is stated in the opposite way than its usual way. Figurative language is mostly used by writer in such different way so it has different effect on readers. It can be found in written or spoken expressions. Many of the expressions need special imagination and conceptualization to interpret their meanings.

Collie and Slater (1987) suggest four main reasons of introducing figurative and metaphorical language: it offers valuable authentic material, cultural enrichment, language enrichment and personal involvement. Similarly, Carter and Long (1991) categorize the reasons under three headings, namely, the cultural model, the language model and the personal growth model, each of which copes a particular set of learning objectives for students.

Lakoff and Johnson (1980) have shown that everyday metaphors in a language are culturally as well as perceptually based. Bonvillain (2003) argued that linguistic analysis, particularly of words and expressions, reveals underlying concepts, beliefs, and values. Thus, the analysis of figurative expression in language can expose underlying concepts as well as the culture of its speakers. Essentially, there has been a movement from considering figurative language as figures of speech to the broader term "figures of thought" (Lakoff \& Johnson, 1980).

Boers and Lindstromberg (2008) further explain that figurative language may be learned in the EFL classroom in a number of ways. For instance, some can focus on the literal meaning of the key word which is used figuratively (e.g. joint in joint account). We can also resort to the mnemonic potential of the expressions to be learned. For example noticing how sounds in many formulaic expressions are repeated, such as alliteration (e.g. play a part), rhyme (e.g. wear and tear), and assonance (e.g. turn a blind eye to). It is also possible to use the property of evoking a mental image that some figurative expressions have (e.g. she hit the ceiling) as another mnemonic tool. In fact, according to them using mental imagery has become part of pedagogic approaches to idioms, inspired by ideas from the cognitive semantics school of thought.

Furthermore, under cognitive semantic approaches, the imagery of idioms and figurative expressions is utilized in the classroom to show learners that figurative expressions may be motivated by underlying conceptual metaphors or metaphoric themes, as in the case of the expressions Your claims are indefensible, He attacked every weak point in my argument and His criticisms were right on target. (Boers \& Lindstromberg, 2005; Lakoff, 1987).

Van Dijk (1995), defines that newspapers are probably a type of a written discourse which most readers are confronted with most regularly. Newspaper can be used by teachers to provide materials for students to learn more vocabulary specifically about figure of speech. Students can not only be encouraged to interpret certain expressions into some actual perspectives but also to learn other cultures from the expressions.

Figurative meaning and vocabulary have a great relationship that is reciprocal relationship in which both of the aspects give a mutual exchange of advantages. It can be stated that learning figurative language will help us build our vocabulary or in another way around learning vocabulary can also mean learning figurative language. Figurative meaning and semantic also have a great relationship because without the knowledge of the meaning of the word, even connotative meaning, it is difficult to understand figurative meaning. Of course, the meaning of the expression will become odd or not understandable. Therefore, figurative language becomes essential in the learning of vocabularies. While, learning of vocabularies support the learning of semantics (Tarigan, 1995). 
Learners of English must be encouraged to see that not only fiction writers but also newspaper journalists resort to figurative language in order to convey concepts originally developed by and addressed to a different audience (Di Bari \& Gouthier, 2004). Lexically, the most important code to convey both connotative and denotative meaning to the readers is by using simple, short, precise and appropriate words (Ifantidou, 2009).

For beginners, junior and senior high school students, understanding figurative language have been difficult. Students find it hard to conceptualize meanings of the expressions written figuratively. They tend to catch the meaning literally without going further to the real meaning implied in the expressions. So, as a language form, figurative expression is important to be taught at schools or learned by anyone in order to understand meaning expressed in a text containing figurative language. This might also make readers interested to read and try to concept the meaning of certain metaphoric expressions in a text. In other words, figurative language plays a big role in representing someone's writing. It certainly gives effect to the language expression either in written or spoken forms.

Some studies have looked at the importance of learning figure of speech in language teaching. The first was a research by Widyanti (2013) explained that there are six types of figurative language which commonly appear in advertisements found in Harper's Bazaar Magazine advertisements: metaphor, hyperbole, personification, simile, metonymy, and synecdoche. Among those types of figurative language, metaphor ranked first. The application of metaphor does not only make advertisements attractive, but also make them informative and persuasive. Next, figurative language mostly appears in the headline of advertisement. The headline is more preferable for readers since it is the theme and center of the advertisement.

The second research was by Yayianti (2015) explained that there are seven types of figurative language employed in the headline and body copy of the advertisements. They are hyperbole, antithesis, parallelism, personification, simile, metaphor and repetition. Each type of figurative language employed in the advertisements has its own functions. The analysis reveals that there are three factors which motivate advertisers to use figurative language in their advertisements. The factors are to grab consumers' attention, to change consumers' behavior, and to aid memory.

The last, a study conducted by
Istiqomah expressions used in advertisements in InStyle Magazine. She found that hyperbole is the most dominant in the advertisements because it is used to persuade to buy the products. It proves that advertisers used figure of speech to make advertisements interesting and persuading.

As already discussed, the use of figurative language in newspaper has been studied by many researches in many areas of different sections of newspaper such as in the advertisement section of a magazine or newspaper, sports rubric, and the headlines. However, none of the previous studies focused on the figurative language in the feature rubric of English written newspaper published in Indonesia by mostly Indonesian news contributors. As a result, there has inadequate information about the use of figurative language used in feature rubrics of the Jakarta Post newspaper of December edition. This study also gives contribution to the researcher herself in which she can find a new way of teaching vocabulary by using newspapers. Next, the rubric chosen was familiar to the students' level and this helps students understand the English learning materials easier.

Other specific aspects we can learn from this authentic material is the language aspect, it is the figurative language. This kind of figurative language can be found in a rubric namely "features". This rubric features many things such as culture, art, famous persons, special events and many others. This rubric is suitable for students, especially junior and senior students as a reading reference because its contents are not too difficult to be digest compare to other rubrics of the Jakarta Post such as; politics, economics, education, national, 
opinion, city, world, supplement, sport and other topics in other rubrics. Furthermore, the information given are so informative for students. Specifically, to enrich students' vocabulary they can find figurative language here. This language aspect can be learnt at the same time while reading the rubric.

Since the Jakarta Post is the only English newspaper distributed in Indonesia including Pagaralam city in South Sumatera, it is worth-study for lecturers, teachers, students and those people who have interest in English not only to read but also to learn any language aspects found in the newspaper. It is also quite easy for us to buy in magazines agency because it has such a large selling area across Indonesia, while others are hard to find. Lecturers who teach reading for example, can use this authentic material for Extensive Reading because this is the only source available.

\section{METHOD}

\section{Research Methodology}

This study used qualitative method to analyze the data. Qualitative research involves data collection procedures that result primarily in open-ended, non-numerical data which is then analyzed primarily by non-statistical methods (Dornyei, 2007, p. 24). Specifically, this study used content analysis method.

Content analysis is a research technique for making replicable and valid interferences from texts to the context of their use. Qualitative content analysis involves any kinds of analysis where communication content (speech, written text, interview, images, etc.) is categorized and classified (Krippendorf, 2004.) Quantitative content analysis is now used for a variety of research problems. Next to specifically textoriented analysis, it can also be sender/production-oriented to study the influence of ownership, organizational routines and rules when it becomes integrated into studies of international media flows, media organizations, professionals, production of media content. Content related in order to analyze the influence of media content on individuals' opinions or on wider socio-cultural, economic or political processes.

Content analysis is probably the oldest way of studying the media and is an answer to the age-old concern with media content. The basic concern was, and is, with how media contents reflect or interpret social, cultural and political norms, attitudes, beliefs and values. As such many sociologists throughout this century (starting with Max Weber) were interested in content analysis as a means of 'monitoring the "cultural temperature" of society' (Hansen et al., 1998, p. 92).

The concern of this theory is oriented precisely toward the relationship 'between the "text" as a social construction and its form or its imputed audience-derived meaning' (Manning and Cullum-Swan, 1994, p.464). Qualitative, interpretative content analysis, then, is aimed at the reconstruction of what could be termed the 'meaning structure' of the text or content. The problematic in this kind of research usually refers to the relationship between characteristics and patterns within the 'text' and the context of the material. As a new bold (Hansen et al., 1998, p.131), underline, the methodology relies heavily on the reading of the text by the researcher, so on his/her interpretation. Compared to the quantitative approach, qualitative content analysis is usually concerned with smaller bodies of material to be analyzed.

In this research content analysis is an analytical approach based on established categories and the types of the object found in the "Feature Rubric". This method is used to describe relative meanings between figurative language and the expressions used.

\section{Object of the Research}

The Jakarta Post is the object of the research data, this newspaper is targeted at Indonesian business people, well-educated Indonesians, and foreigners. The Jakarta Post has won several awards and been described as being "Indonesia's leading English-language daily". The Jakarta Post is a member of Asia News Network. Besides printed edition, The Jakarta Post also features an online edition, 
which includes exclusive stories that are free to access.

The data of this study were obtained from "feature", a rubric in The Jakarta Post which is usually written on page 19 to 20 of each edition. In this study, the data analyzed were the figurative lexicons in "feature" December 22017 until December 302017. There were 9 days with no publications because they were holidays (Dec 12017 was Maulid Nabi Muhammad SAW, 24, 25 and 26 were Christmas and 3, 10, 17, 24 and 31 were Sunday). This means that there were only 23 days editions published during December.

This newspaper was selected because it is a daily English language newspaper in Indonesia with the largest circulation. The expressions were read comprehensively and selected from the "feature" in The Jakarta Post. From 23 editions, it was found that there were 80 expressions of figurative lexicons used in "feature". From those 80 expressions, there were 72 expressions in which researcher and the corater agreed to be the data of the study.

\section{Instrument of the Research}

Checklists structure a person's observation or evaluation of a performance or artifact. They can be simple lists or criteria that can be marked as present or absent, or can provide space for observer comments. These tools can provide consistency over time or between observers. Checklist can be used for evaluating databases, virtual IM services, the use of library space, of for structuring peer observations of instruction sessions. (www.alaworkshopdata.wordpress.com).

Generally the aim of using checklist is to obtain a concise and coherent description of the system in terms of objects, attributes, functions, relation between objects as well as between objects and functions, dialogue states, selections and estimate usability. Ideally a checklist used for testing purposes should take up the matric that is being applied, the measurement technique, and most importantly, the related quality characteristics. (Retrieved from www.issco.ugine.ch) To collect the data from the newspaper, checklist was used as the research instrument.

\section{Data Analysis Procedure}

The following was the procedure of the research in conducting the study:

1. Read the text comprehensively in order to find the expressions considered using figurative language.

2. Identified the phrases containing the figurative meaning by paying attention to use of non-literal words and imaginative way.

3. Note taking the expressions into notes in order not to miss any expressions found from the texts.

4. Classified the figurative lexicons based on their types (metaphor, simile, personification, hyperbole, apostrophe, metonymy, synecdoche, symbol, image, paradox, litotes, irony, allegory, allusion, repetition, tautology, alliteration, para rhyme, parallelism, and oxymoron).

5. Classified the types of the meaning of the figurative lexicon found based on Leech's theory (conceptual meaning, social meaning, affective meaning, thematic meaning, collocative meaning, connotative meaning, and reflected meaning).

6. Grouped the types of figurative lexicons and the meaning of the figurative lexicons found into the checklist forms in order to be wellorganized and easily read.

7. Drew conclusion by comparing the result of the study to the co-rater's result in order to be valid and reliable to answer the questions addressed.

\section{Technique for Analyzing Data}

The processes of data analysis in this research were based on the following stages. First, the researcher read the text comprehensively. Second, the researcher noted down all the expressions containing figurative language. Third, the researcher analyzed, classified and grouped the expressions based on their types of figurative language and types of 
meaning by using the checklist form. Fourth, the researcher interpreted the meanings of the figurative lexicons by referring to the theories used in the study. After interpreting, the researcher did the checklist. Finally the cross checked her analysis to the co-rater and described the result statistically and drew some conclusions to answer the questions proposed in the study.

The result of the study analysis presented in the form of description and discussions. Description would give the readers, background and context analysis of the expressions explain in order to be rich and thick. Meanwhile discussions would represent personal and theoretical understanding of the phenomenon of the study.

\section{Triangulation}

Triangulation is a process of verification that increases validity by incorporating several viewpoints and methods. In the social sciences, it refers to the combination of two or more theories, data sources, methods or investigators in one study of a single phenomenon to converge on a single construct, and can be employed in both quantitative (validation) and qualitative (inquiry) studies. Discussions about whether and how to combine social research methods go back to debates about the use of survey and fieldwork or the use of interviews and participant observation. Most recently, the debates about the relationship between quantitative and qualitative methods as viewed by Blaikie (1991), particularly in evaluation research, have advocated a combination of methods of different types of research. The purpose is to increase the credibility and validity of the results. Often this purpose in specific contexts is to obtain confirmation of findings through convergence of different perspectives.
In fact, there are many different approaches to 'triangulation' and there are articulate proponents for each approach.

This study used theory triangulation to help interpret and explain the data gained from the study in order to be valid and reliable. This research crossed check the theory of the experts used, the judgment from the co-rater pointed and the study of the researcher herself. For example, in order to find the meaning of certain figurative lexicons found, the meaning needed to be defined by referring to the theories reviewed, corater judgment, the researcher herself, and other supporting sources like dictionary, books or internet. After this phase, the data were verified by the co-rater pointed to be judged whether they were correct or incorrect.

\section{RESULTS AND DISCUSSION}

The data of this study were obtained from "feature", a rubric in The Jakarta Post. This study employed data triangulation analysis to check the reliability of the textual analysis.

The result of the inter-rater reliability between the researcher and the co-rater was almost perfect or ninety percent $(90 \%)$ agreed to the data obtain from the "feature". This means that the agreement needed as reliable and valid data of study could be accepted. Therefore, the final result of this study based on the research questions addressed, are as the following:

\section{The Types of Figurative Language found in "Feature" of The Jakarta Post}

The first analysis of this study is on the figurative lexicons used by the writer in "feature". The data analysis indicated that the figurative lexicons found in "feature" based on the theory of figurative language by Perrine is presented in the table below.

Table 1. Frequency of types of figurative lexicons found in "feature" of The Jakarta Post.

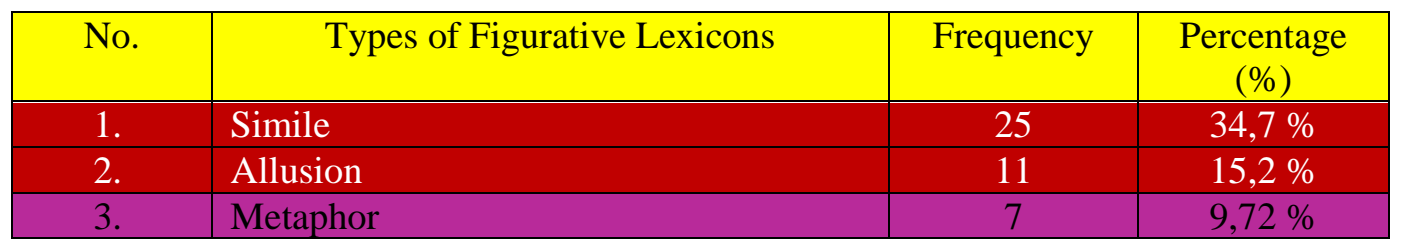




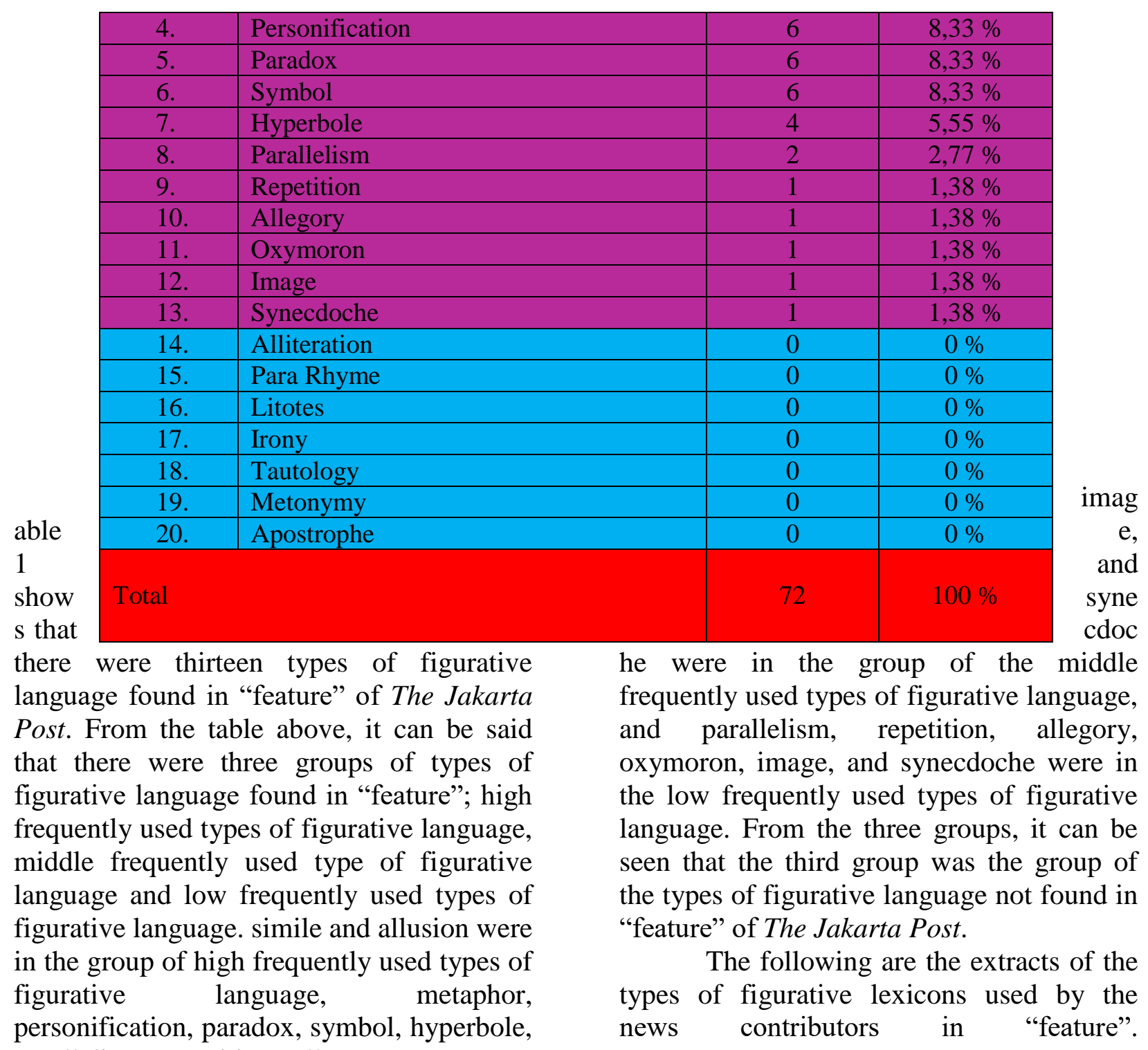

Extract $1 \quad$ : Simile

During a tour initiated by cellular telecommunication operator XL Axiata, The Jakarta Post also stopped by Banda Aceh to observe the icon of provincial, Baiturrahman Grand Mosque. Built by Sultan Iskandar Muda Mahkota Alam in 1612. Its beauty and magnificence resemble the grandeur of Taj Mahal in India.

In extract 1 , the key word is "resemble". This indicates that the type of figurative language used is Simile. Here, the writer gave such help clue to imagine that Baiturrahman Grand Mosque is similar to Taj Mahal in India.
By having similarity to Taj Mahal, reader could use their imagination to imagine the two objects being compared, and this kind of comparison helps readers understand the information easier.

\section{Extract $2 \quad$ : Simile}


It was apparent that many, many people at the festival grounds were waiting for the rainbow-colored, sticky-sweet EDM of Marshmallow, the DJ notable for wearing a marshmallow-shaped bucket in his head. People rushed, ran and some literally fell down running toward the main Garuda stage just to secure a spot at the day's most waited-for set. Decoy Marshmallow buckets and masks were everywhere in the crowd. Sweat flowed from everywhere like torrential rain. It was almost too much to bear.

In extract 2, the key word is "like".

Here, the sweat which flowed from everywhere is compared to a torrential rain.

Extract $3 \quad$ : Simile

In another work, Space to Human Behavior, He treated the bamboo using contemporary methods to create a tunnel where the bamboo would move and made sounds similar to that produced by a traditional music instrument called an angklung.

In extract 3, the key phrase is "similar

like a tunnel which would move and made to". In this expression, the bamboo was treated

sounds to that of angklung would do.

Extract $4 \quad$ : Allusion

You might not be familiar with Tino if you are a member of Generation Z, a label given to those born after 1995 .

In extract 4, the key word is "Generation

find what Generation $\mathrm{Z}$ referred to in order to Z". This is an Allusion. Here, readers had to understand the reference of the word used.

Extract $5 \quad$ : Allusion

She has taken a number of freelance jobs probably to keep her mind engaged. But when you work as a consultant offering your services to your clients, you are no longer "the Queen."

In extract 5, the key phrase is "the queen". In this expression, the phrase "the queen" does not mean the queen of a country or a nation but a reference to someone's position in

Extract $6 \quad$ : Metapor

Karangturi-a heaven her job. Here, the phrase means someone who is no longer a boss but only someone who offers her services to earn money.
Islamic school live is described as a high tolerance village) was compared to a place like a heaven in which tolerance become the characteristic of the village itself. Karangturi (a village in Rembang, Central Java
in which many Chinese and santri or students of Karangturi (a village in Rembang, Central Java
in which many Chinese and santri or students of

The sixth extract is a metaphor, in which the title implied the comparison of two different
things. Here, the writer indirectly stated that

\section{Extract $7 \quad$ : Personification}

"Thousands of words and stories were cheerfully dancing in my mind while I was doing my labor job. I wrote them on my imaginary paper. With that, I survived the extreme hardship." 
In extract 7, the phrase "cheerfully dancing" is the key words. Here, the phrase "thousands of words and stories" are given the characteristics of human being (cheerfully dancing). "Words" and "stories" are non living objects but described as cheerfully dance like a human. This figurative lexicon considered as personification.

\section{Extract $8 \quad$ : Paradox}

What's so engaging about the film is that it feels like a series of vignettes culled from Soleh's recollection of his time at the university. That's why he plays a fictionalized version of himself; he breaks the fourth-wall to explain why he plays himself in movie: Because he looked old when he was young and also, the actor Reza Rahardian "is in too many movies.

The key words of extract 8 are "old" and "young". These two words are categorized as paradox because they gave contradiction that is

Extract $9 \quad$ : Symbol

Through the film, the viewer is able to see that it was manily Soleh's carefree viewpoint of life that he is today. He admitted that he had never had any ambitions, and that his success in life were purely the fruits of his own insticnts. nevertheless somehow true of the situation. The age was still young but looked old.
In extract 9, the key word "fruits" symbolizes the result of someone's success. It could be seen from someone's material, wealth,

Extract $10 \quad$ : Hyperbole

"It was the most thrilling two minutes of my life and it helped me forget all my troubles" said Safina, a visitor from Malaysia.

The exaggeration in the expression of extract 10 is clear a hyperbole. It doesn't expect way of life or other things which give opinions to other people that someone is rich or successful already.

Extract $11 \quad$ : Parallelism

"Right now, I would say that I picked the name because nice is the middle way to many ways-not too good, not too bad," said Resha the ABC was chosen because it was simple-"something the kids understand."

In extract 11, the two pieces of "not too" are gramatically the same or similar in their

\section{Extract 12 : Repetition $\underline{\text { God's }}$}

Extract 12 is a Repetition. The key word "God" is repeated for twice in order to make the idea clear. Here, the emphasis is in the word to be taken seriously that only in two minutes, people can forget all their troubles of life.

\section{Extract 13 : Oxymoron}

constructions. This is called parallelis

When I returned there, my students had obviously graduated from the school. I happened to recall some encounters with my favorite students in a washroom and in the library. I was overwhelmed with bittersweet sentiment. I tried holding 
onto the memory, but it is like gold dust that keeps slipping out of your hands the tighter you grasp it.

In extract 13 the key words bitter and sweet (bittersweet) has two opposite ideas which are joined to create an effect that something is at the same time bitter but also sweet. 
Extract $14 \quad$ : Synecdoche

Saraswati learning centre-a special place for the gifted.

Extract 14 is a synecdoche in which the key phrase "the gifted" implies the use of a part for the whole. The word the "gifted" refers to those children belong to lack of ability or disable who are accepted to study in the learning centre owns by Saraswati. They called them the gifted or children borned with speciality from God.

\section{Extract $15 \quad$ : Allegory}

The New Order narrative at that time was that the PKI was backed by the communist Chinese government, and during the Cold War period, it was clear that Soeharto's regime opted to side with the United States to fight the growing influence of communism in Southeast Asia.

In extract 15 the key words "New Order" refers to a description of years in 1990's in which at that time Soeharto ruled Indonesia and then dethrone by the revolution in 1997. This is an allegory.

Extract 16 : Image

The film in which he is technically the star and the focus, is framed as an autobiography of the comedian's seven years as a communications student at Padjajaran University (Unpad) in West Java- a place that he describes as "incredibly dull for people like him".

In extract 16, the key word "dull" gives an imaginary effect to the reader. Directly,

\section{The Types of Meanings of Figurative Lexicons Found in "Feature" of The Jakarta Post}

The second focus of this study is on the types of meanings of figurative lexicons found someone will imagine a dull situation when he or she comes across this word.

in "feature". The table indicated that the frequency of the types of meanings of figurative lexicons found in "feature" is as illustrated below.

Table 2. Frequency of types of meaning of figurative lexicons found in "feature" of

The Jakarta Post.

\begin{tabular}{|c|l|c|c|}
\hline No. & \multicolumn{1}{|c|}{ Types of Meaning } & Frequency & $\begin{array}{c}\text { Percentage } \\
(\%)\end{array}$ \\
\hline 1. & Conceptual Meaning & 36 & $50 \%$ \\
\hline 2. & Reflected Meaning & 16 & $22,2 \%$ \\
\hline 3. & Connotative Meaning & 13 & $18,1 \%$ \\
\hline 4. & Social Meaning & 3 & $4,16 \%$ \\
\hline 5. & Affective Meaning & 1 & $2,77 \%$ \\
\hline 6. & Thematic Meaning & 1 & $1,38 \%$ \\
\hline 7. & Collocative Meaning & 72 & $1,38 \%$ \\
\hline & Total & & $100 \%$ \\
\hline
\end{tabular}


Table 2 reveals that there were seven types of meanings found in "feature" of The Jakarta Post. From the table it is also found that there are three categories of the types of meanings of figurative lexicons found in "feature". The first category is the high frequently used category, which was conceptual meaning, the second category is the middle frequently used category, which were reflected meaning and connotative meaning and the third category is the low frequently used category, which were social meaning, affective meaning, thematic meaning and collocative meaning.

This could be inferred that even though figurative language usually use non-literal words and imaginative ways to convey the messages in the expressions, but the meaning suggested in the figurative lexicons used by the writer in "feature" were highly dominated by conceptual meaning.

Here are the extracts of the types of meanings of figurative lexicons found in "feature".

\section{Extract 17 : Conceptual Meaning}

The exhibition, which is up and running until March 18 next year, correlates either Issue-wise or time-wise, denoting a conceptual vision that fits the spirit of our time.

The key word "wise" in the above extract implies a conceptual meaning. It is understood that "wise" is a referent to the real meaning of itself in the real world. When someone reads the word "wise", he or she would

Extract 18 : Conceptual Meaning

In other Indonesian romantic drama, such as Melbourne Rewind or Love in London, it is all too obvious that the main characters are Indonesians, as they bring their hometown attitudes, mannerisms, and perceptions into an unfamiliar setting. Those characters stick out like sore thumbs and do not blend in with the foreign environment, with the result that the movies themselves look disingenuous and overly obsessed with the Indonesian identity, creating the impression that the directors are underestimating the intelligence of Indonesian moviegoers.

In extract 18, the key word "like" as the adjective acts as a reference of its own meaning and its meaning can be accepted in the real world. This extract is conceptual meaning refer to something which is having or showing experience, knowledge, and good judgement. In this case, "wise" means having good judgement on the issue and the time to visit the exhibition. because "like" here acts ask a reference in which that the characters are like the sore thumbs. common or similar to each other. Means that both things have something in

Extract 19 : Conceptual Meaning

Another entry to the nostalgia sweepstakes is the Polaroid OneStep 2, the first true Polaroid to hit the market since the company stopped producing them in 2008. Eschewing all the modern add-ons that come with similar retro camera gadgets of recent years, the OneStep 2 stays true to its origin, for better or worse, focusing more on capturing feeling.

In extract 19, the key words "better" and "worse" represent their real meanings and they are referent to the real world. "Better" here 
standard; less good or desirable. So, for better or worse implies that whatever the results, whether

\section{Extract $20 \quad$ : Reflected Meaning}

Her utmost dream now is to translate all of her books into Chinese to allow people to read them. "I also hope my books become a window for the world to see China was like".

In extract 20, the word "a window" does not simply mean a window of a house, building or others but it rather had multiple reflected meanings. Here, the writer suggested that a window (the books) could possibly mean a

Extract $21 \quad$ : Reflected Meaning I think the elephant in the room is Amazon," said Donna Paz Kaufman, a Florida-based industry consultant. "Anybody in publishing is concerned about the tremendous market share that Amazon has garnered."

In extract 21, the key word "elephant" suggests a reflected meaning. Here, readers need to analyze the word "elephant" to its implied meaning. It is not an animal but a reflection of

Extract 22 : Connotative Meaning

"Five years ago, I was asked (by the Embasssy of Italy) to design sculptures that represent Italy. They asked me to look at Michelangelo," Sarano said, adding that the two Affairs as a symbol of Italy's culture heritage in US.

In extract 22, the key word "Michelangelo" has a connotative meaning in which reader has to refer to it in order to know who Michelangelo was, and what works had he

\section{Extract 23 : Social Meaning}

Danu for instance, who dabbles in eerie martial arts, is heavily focused on cashing out on his "skill"; Dedy goes home to a nagging wife, but is ultimately a doting family man; Lilo is mama's boy who has stopped out of his comfort zone by the time the credits roll. And then there's Yanto, helplessly love struck.

In extract 23, the key word "mama" has relation to sosial structure in the society. The word "mama" usually refers to a social status of someone and is usually used by someone who has higher status in the society. It is usually used produced. If we hear the word Michelangelo, the connotation would be famous works of Michelangelo such as paintings.

Extract 24 : Affective Meaning

"When he was creative, he puts his entire body and entire spirit into it," Intan said. 
Extract 24 is an Affective Meaning. Here, the meaning of the sentence reflects the personal feeling of the speaker toward Extract 25 : Thematic Meaning something she is talking about. Intan described that when her husband was creative, he puts his entire body and spirit into his work of art.

When I returned there, my students had obviously graduated from the school. I happened to recall some encounters with my favorite students in a washroom and in the library. I was overwhelmed with bittersweet sentiment. I tried holding onto the memory, but it is like gold dust that keeps slipping out of your hands the tighter you grasp it.

Extract 25 is a Thematic Meaning. Here, what is intended to be stressed is the subject of the sentence. The indication is that the speaker wants to organize the message in term of

Extract 26 : Collocative Meaning

These are of course elements that were in turn borrowed from rock fore-bearers, The Beatles, T-Rex, and suchlike. In other words, they are catchy as hell, as good as the few single from those lesser albums or on par with the non-single tracks from Definitely and Morning Glory. This quality runs elsewhere. emphasizing. Here, the speaker wants to emphasize that he was overwhelmed with the bittersweet sentiment.
The key phrase "catchy as hell" is considered as collotative meaning. It is because the meaning is likely to use only in certain ways not as other general or common words or phrases commonly used by people in general.

\section{DISCUSSIONS}

\section{Types of Figurative Lexicons found in "Feature" of The Jakarta Post.}

As the result found, there were thirteen types of figurative lexicons found in "feature" of The Jakarta Post's December editions and the highest frequently used type of figurative lexicons found was simile. The important of simile here is that similes help create a vivid image in the readers' minds by comparing their subjects with known events or things. In everyday conversation as well as in writing and formal speeches, similes are used to clarify ideas, create memorable images, and emphasize key points. (English Language Art Skill \& Strategies, 2005).

Other possible reasons for this is probably due to some reasons such as the type of the text and the culture background. In "feature",
The phrase "as hell" here gives an emphasis that the song is really catchy that its course elements has the quality of those of rock fore-bearers such as The Beatles, T-Rex and others. the news present are mostly about popular writings. Of course, this type of text will be different from those of literary works such as novel, poetry, short story and drama script in which the use of the figurative language as literary device give extra beauty to the writing itself. Authors use similes for several reasons, but the most obvious one is illustrative. Writers want to create lasting impression in the reader's minds (Butler R, 2016)

Another reason is probably because of the culture background of the news contributors themselves who are mostly Indonesians. As Indonesian writers, contributors of news need to consider the market of the newspaper itself. They have to see that the news they bring into the presentation are based on the culture of Indonesian people. If they break the ethic for instance, the news might bring bad effects to the 
society, and the impact will be to the reputation of the newspaper itself. William W (as cited in Wilstach F. J, 1916) found that a newspaper, like a theatre, must mainly owe its continuance in life to the fact that it pleases many persons; and in order to please many persons it will, unconsciously perhaps, respond to their several tastes, reflect their various qualities, and reproduce their views.

This implies that the use of figurative language especially simile in the expressions used in "feature" of the Jakarta Post indirectly limited by the freedom of the expression due to the text type and culture background of the newspaper buyers. There is somehow a tendency to fulfill the tastes of the newspaper readers. Simile makes the writing (and reading) more interesting and lyrical. Similes spark your reader's imagination while getting the information across. They help the readers "see" the scene in their heads. (Lebel J, 2016)

\section{Types of meanings of Figurative Lexicons found in the Jakarta Post.}

The table of frequency of types of meanings of figurative lexicons found in "feature" reveals that conceptual meaning was the most frequent type of meaning used by mostly of the news contributors in "feature". Conceptual meaning was the most type of meaning found in "feature". This inferred that even though in general, figurative language usually characterized by non-literal words and

\section{CONCLUSION AND SUGGESTION}

From the data analysis of figurative lexicons found in "feature", this study uncovered that the most type of figurative language used was simile at the frequency of use close to thirty five percent $(35 \%)$. It can be said that many writers who contributed in "feature" of The Jakarta Post tend to use simile to deliver the messages they want to convey.

From the types of meaning of figurative lexicons found in "feature", the study revealed that fifty percent $(50 \%)$ of types of meanings of figurative lexicons was conceptual meaning. use imaginative way to suggest the idea in written or spoken expressions, this study found that the use of conceptual words or dennotative words was the most frequent in use in "feature" of The Jakarta Post. In other words, it can alsa meant that the conceptual words used primarily as the first component to build the sentences' meanings. Conceptual meaning may be defined as logical meaning, the meaning used to convey ideas in order to describe the world (Goatly A, 2012). It has been acknowledged, and is indeed popularly assumed, that the major function of human language is that of expressing a conceptual content (Leech, 1980).

In semantics, conceptual meaning is the literal or core sense of a word. Also called denotation or cognitive meaning. Contrast with connotation, effective meaning and figurative meaning (retrieved May 28, 2018, from http//:www.thought.com). This means that literal words give more contributions in the meanings as they reflect the words as they are in the real world. It is easier for readers to concept literal words rather than words, phrases, or expressions written figuratively. Moreover, denotative words are easy to be understood as they are according to their structures and use to those of syntactic and phonological aspects. It can be concluded that types of figurative lexicons used in certain texts will likely depend on the contents and also the types of news deliver to the readers by the news contributors.

Even though most words use in metaphorical expressions are non-literal and imaginative, however, the study indicates that the writers in "feature" still used literal words as the primary words to deliver the messages on issues they brought to the writings in "feature" of The Jakarta Post.

This study finds that simile was the most frequently used type of figurative language in "feature" and conceptual meaning was the most frequently used type of meanings in "feature" of The Jakarta Post. However, this study covers only both of the language aspects mentioned above in one of the rubrics in The Jakarta Post. 
As there are many other rubrics can be learnt or analyzed, it is suggested for other researchers to discuss other rubrics of the newspapers. This type of authentic material has wide range of aspects to be offered, for example for extensive reading and vocabulary building, so it is very welcome for other researchers to conduct variety of studies by using newspapers or other similar types of authentic materials like magazine or internet as the objects of their study. Furthermore, in discussing simile it is suggested that the discussion can cover wider or larger scope of study in The Jakarta Post, not limited by one or some rubrics only.

Important to be mentioned, the previous studies in this study is extremely limited. Many analyzed types of the figurative languages used in advertisements but none was found analyzing "feature" rubric. More or less, this limitation will affect the conclusion of this study.

At last, the findings of this study have the potential implications for teaching not only the types of figurative language but also the types of meanings to the students at school. Furthermore, this type of learning can help students with their vocabulary building, reading fluency, and enriching cultural knowledge and personal involvement of the readers. It is also suggested that the discussion about simile and conceptual meaning in the teaching and learning process at schools can be given more proportion.

\section{REFERENCES}

Baghda, K. N. (2011). A short introduction to semantic. Journal of language teaching and research, Vol. 2, pp. 1411-1419. doi:10.4304.

Bell, A. (1999). The language of news media. oxford UK and Cambridge MA: Blakwell.

Boers, F \& Lindstormberg, S. (2008). Cognitive linguistic approaches to teaching vocabulary and phraselogy. Berlin: Mount de Gruyter.

Bonvillain, N. (2003). Language culture, and communication: The meaning of messages ( $\left.4^{\text {th }} \mathrm{ed}\right)$. Englewood Cliffs: New Jersey. Prentice Hall.

Butler, R. (2016). Why do authors use similes?. Retrieved May 25, 2018 from http://www.quora.com.

Cann, R., Kempson, R. \&Gregoromichelaki, E. (2009). Semantics: An introduction to meaning in language. Cambridge: Cambridge University Press.

Carter, R \& Long, M. (1991). Teaching Literature. London. Longman.

Cmeil, K. (1990). Democratic Eloquence: The fight over popular speech in nineteentcentury america. University of California Press.

Collie, J. \& Slater S (1987). Literature in the language classroom: A resource book of ideas and activities. Cambridge: Cambridge University Press.

Crystal, D. (1991). A dictionary of linguistics and phonetic. Cambridge: Basil Blackweel Ltd.

Dennotation and connotation. Retrieved May 18, 2018 from http//www.nps.gov/archieve/manz/ed_lo aded_words_deno_cono_htlm.

Dornyei, Z. (2007). Research methods in applied linguistic: Quantitative, qualitative and mixed methodologies. Oxford: Oxford University Press.

Fromkin, V. (1983). An introduction to language. New Year: Holt, Rinehart and Winston.

Gibbs, R. W. (1994). The poetics of mind figurative thouhgt, language, and understanding. California: Cambridge University Press.

Goatly, A. (2012). Meaning and Humour. Cambridge University Press.

Greenman, R. Creating similes in news, sports, and feature writing. Retrieved May 21, 2018, from www.greenman robert.com.files.GREENMAN_5_WEB 
_SITE_NYT_SIMILES_IN_NEWS_SP

ORTS_AND_FEATURE.

Hadges , J. C. (1967). Harbrace college book. New York.

Hawks, T. (1972). Metaphor.

Hipkiss, R. A. (1995). Semantics: Defining the discipline. New Jersey: Lawrence Erlbaum Associate Inc.

Hurford, J. R. (2001). Semantics: A coursebook (2nd ed.). New York: Cambridge University Press.

Istiqomah, A. (2014). An analysis of figurative expressions and the meaning used in the advertisements in instyle magazine. English Department, Faculty of Humanities Dian Nuswantoro University.

Katz, J. J. (1972). Semantic theory. New York: Harper and Row.

Keiko, T. (1994). Advertising language: A pragmatic approach to advertisement in Britain and Japan. London: Routledge.

Kennedy, X. J., \& Gioia, D. (2005). An introduction to poetry. New York: Longman.

Keraf, G. (2001). Diksi dan gaya bahasa. Jakarta: PT. Gramedia Pustaka Utama.

Kreidler, C. W. (1998). Introducing english semantic. New York: Routledge.

Krippendorff, K. (1989). Content analysis. In E. Barnouw, G. Gerbner, W. Schramm, T. L. Worth, \& L. Gross (Eds), International encyclopedia of communication (Vol. 1, pp. 403-407). New York, NY: Oxford University Press

Lakoff, G., \& Johnson, M. (2003). Metaphors we live by. Chicago: The universityof Chicago Press

Lebel, J. (2016). Why do authors use similes?. Retrieved May 25, 2018, from http:///www.quora.com.
Leech, G. (1969). A Linguistic Guide to English Poetry. New York: Longman Inc.

Leech, G. (1980). Explorations in Semantics and Pragmatics.

Leech, G. (1981). Semantics: The Study of Meaning, 2nd Edition. London: Penguin Book.

Lyons, J. (1977). Semantics. Cambridge: Cambridge University Press.

Palmer, F. R. (1976). Semantics a new outline. Cambridge: Cambridge University Press.

Perrine, L. (1991). Sound and sense. London: Harcourt Brace College Publisher.

Potter, H. (1967). Figurative language in psychology, psychotherapy and education. Hillsdale, N.J: Lawrence Erlbaum. Mezo, R. E. (1999). "Fire i' the blood": A handbook of figurative language. USA: Universal publisher.

Mezo, R. E. (1999). "Fire $i$ ' the blood": A handbook of figurative language. USA: Universal publisher.

Risdianto, F. (2011). Introduction to literature. Yogyakarta: Trust Media Publishing.

Stamatelou. M. (2015). A reflection on the use of advertisement in enabling language learning in the EFL classroom. ELTED Winter. (17), 27-34Tarigan, H. G. (1995). Pengajaran semantik. Bandung: Angkasa.

Tarigan, H. G. (1995). Pengajaran semantik. Bandung: Angkasa.

Widyanti, N. (2013). A stylistic-pragmatic: Analysis of figurative language in Harper's Bazaar magazine advertisement (A thesis). English Education Department. Yogyakarta State University

Willie, M. (1979). The mass media and language development. Australian journal of teacher education. 4 (2). 
Wilstach, F. J. (1916). A dictionary of similes. Retrieved May 18, 2018 from www.bartleby.com Yayianti, T.K. (2015). An analysis of figurative language used in cosmetic advertisements in the internet. English Department Faculty of Cultural Sciences, Sebelas Maret University. Solo.

Yayianti, T.K. (2015). An analysis of figurative language used in cosmetic advertisements in the internet. English Department Faculty of Cultural Sciences, Sebelas Maret University. Solo.

Van Dijk, T. A. Power and the news media. University of Amsterdam.

Van Dijk, T. A. (1988). News as discourse. Hillsdale, New Jersey: Erlbaum.

Van Dijk, T. A. (1988). News analysis. Case studies of international and national news in the press. Hillsdale, New Jersey: Erlbaum. 